\title{
In Vivo Growth Factor Expansion of Endogenous Subependymal Neural Precursor Cell Populations in the Adult Mouse Brain
}

\author{
Constance G. Craig, ${ }^{1}$ Vince Tropepe, ${ }^{1}$ Cindi M. Morshead, ${ }^{1}$ Brent A. Reynolds, ${ }^{2}$ Samuel Weiss, ${ }^{2}$ \\ and Derek van der Kooy ${ }^{1}$
}

1Neurobiology Research Group, Department of Anatomy and Cell Biology, University of Toronto, Toronto, Ontario, Canada M5S 1A8, and 2Departments of Anatomy and Pharmacology and Therapeutics, University of Calgary, Calgary, Alberta, Canada T2N 4 N1

The lateral ventricle subependyma in the adult mammalian forebrain contains both neural stem and progenitor cells. This study describes the in situ modulation of these subependymal neural precursor populations after intraventricular administration of exogenous growth factors. In vivo infusion of epidermal growth factor (EGF) into adult mouse forebrain for 6 consecutive days resulted in a dramatic increase in the proliferation and total number of subependymal cells and induced their migration away from the lateral ventricle walls into adjacent parenchyma. Immediately after EGF infusion, immunohistochemical characterization of the EGF-expanded cell population demonstrated that $>95 \%$ of these cells were EGF receptor- and nestin-positive, whereas only $0.9 \%$ and $0.2 \%$ labeled for astrocytic and neuronal markers, respectively. Seven weeks after EGF withdrawal, $25 \%$ of the cells induced to proliferate after 6 d of EGF were still detectable; $28 \%$ of these cells had differ- entiated into new astrocytes and $3 \%$ into new neurons in the cortex, striatum, and septum. Newly generated oligodendrocytes were also observed. These in vivo results (1) confirm the existence of EGF-responsive subependymal neural precursor cells in the adult mouse forebrain and (2) suggest that EGF acts directly as a proliferation, survival, and migration factor for subependymal precursor cells to expand these populations and promote the movement of these cells into normal brain parenchyma. Thus, in situ modulation of endogenous forebrain precursor cells represents a novel model for studying neural development in the adult mammalian brain and may provide insights that will achieve aduit replacement of neurons and glia lost to disease or trauma.

Key words: subependyma; stem cell; precursor cell; epidermal growth factor; fibroblast growth factor; regeneration
During development, all the cells of the adult mammalian forebrain are derived from a highly proliferative region lining the lateral ventricles called the germinal zone (McConnell, 1988; McKay, 1989). Although the germinal zone contains unipotent precursor cells capable of giving rise to only neuronal or only glial progeny (Luskin et al., 1988, 1993; Grove et al., 1993; Krushel et al., 1993; Levison and Goldman, 1993a,b; Luskin and McDermott, 1994), evidence also supports the existence of multipotential CNS precursor cells in this region that can give rise to both neuronal and glial progeny (Price and Thurlow, 1988; Temple, 1989; Galileo et al., 1990; Williams et al., 1991; Reynolds et al., 1992). In vitro studies demonstrate that embryonic germinal zone precursor cells proliferate in response to basic fibroblast growth factor (bFGF), epidermal growth factor (EGF), and/or transforming growth factor- $\alpha$ (TGF- $\alpha$ ) (Gensburger et al., 1987; Cattaneo and McKay, 1990; Murphy et al., 1990; Anchan et al., 1991; Reynolds et al., 1992; Kilpatrick and Bartlett, 1993). A subpopulation of

\footnotetext{
Received Sept. 19, 1995; revised Jan. 22, 1996; accepted Jan. 24, 1996.

This work was supported by grants (D.v.d.K., S.W.) from the Canadian Networks of Centres of Excellence and the Medical Research Council of Canada, and postdoctoral fellowships from the Medical Research Council of Canada (C.G.C., C.M.M.) and the Canadian Networks of Centres of Fxcellence (C.G.C.). We thank W. Staines for many helpful discussions, and R. Mullen, R. McKay, S. Fedoroff, and $\mathrm{S}$. Hockfield for kindly providing antibodies.

Correspondence should be addressed to Dr. Constance G. Craig, University of Toronto, Department of Anatomy and Cell Biology, Medical Science Building, Room 1105, Toronto, Ontario, Canada M5S 1A8.

Dr. Reynolds' present address: Neurospheres Limited, Caigary, Alberta, Canada T2N $4 \mathrm{~N} 1$.

Copyright (C) 1996 Society for Neuroscience $\quad 0270-6474 / 96 / 162649-10 \$ 05.00 / 0$
}

these embryonic precursor cells appears to be neural stem cells in so far as they demonstrate multipotentiality and exhibit selfrenewal properties (Hall and Watt, 1989; Potten and Loeffler, 1990; Reynolds et al., 1992; Davis and Temple, 1994).

In sharp contrast to the avian CNS, which generates new neurons and glia from endogenous stem cells throughout adulthood (Nottebohm and Alvarez-Buylla, 1993), the mammalian CNS stem cells have long been thought to exist only during embryogenesis (Rakic, 1985). Recent in vitro evidence, however, suggests that the adult brain does indeed contain multipotential neural stem cells (Reynolds and Weiss, 1992; Richards et al., 1992). These in vitro studies demonstrate that (1) the adult murine brain contains cells that proliferate in response to EGF to form spheres of undifferentiated cells; (2) the cells within clonally derived spheres differentiate to form both neuronal and glial progeny; and (3) a subpopulation of these cells proliferate indefinitely when passaged in the presence of EGF. Thus, these adultderived in vitro EGF-responsive cells display the defining characteristics of stem cells: proliferation, generation of differentiated progeny, and self-renewal (Hall and Watt, 1989; Potten and Loeffler, 1990).

The in vivo adult source for these in vitro EGF-responsive stem cells is the subependymal layer lining the forebrain lateral ventricles (Morshead et al., 1994). This region, believed to be a developmental remnant of the embryonic germinal zone (Lewis, 1968; Privat and Leblond, 1972), contains a unique population of constitutively proliferating cells that have a cell cycle time of $\sim 13 \mathrm{hr}$ (Morshead and van der Kooy, 1992). This constitutively prolifer- 
ating cell population, which is undifferentiated, has the potential to differentiate into neurons and glia in vitro (Lois and AlvarezBuylla, 1993), whereas in vivo the postmitotic fate of these cells seems to be either cell death or neuronal differentiation after migration to the olfactory bulb (Morshead and van der Kooy, 1992; Corotto et al., 1993; Lois and Alvarez-Buylla, 1994). The persistence of the constitutively proliferating population throughout the adult life of mammals (Altman, 1969; unpublished results) suggests that a relatively quiescent cell population may exist to proliferate infrequently to repopulate and thus maintain the constitutively proliferating population (Craig et al., 1994). It is this relatively quiescent cell population, not the constitutively proliferating population, that is proposed to be the in vivo source for the in vitro EGF-responsive stem cells (Morshead et al., 1994). The constitutively proliferating subependymal population, which is proposed to be the progeny of relatively quiescent stem cells, would therefore represent neural progenitor cells. The term precursor cell is used to refer to either stem or progenitor cells, without distinction.

To test the effects of exogenous growth factors on adult subependymal neural precursor cell populations in vivo, growth factors were infused continuously over an extended period of time with osmotic pumps attached to cannulae implanted directly into the lateral ventricles. A replication-deficient, recombinant retrovirus containing a $l a c Z$ reporter gene and the proliferation markers $\left[{ }^{3} \mathrm{H}\right]$ thymidine (thy) and bromodeoxyuridine (BrdU) were used to label subependymal precursor cells. Variations of infusion and survival times postinfusion enabled the in vivo characterization of the proliferative and differentiative potential of growth factor-responsive subependymal cell populations.

\section{MATERIALS AND METHODS}

Retroviral labeling and detection. Retrovirus was collected from confluent $\Psi 2 \mathrm{BAG} \alpha$ (ATCC CRL-9560) cells for $48 \mathrm{hr}$ at $32^{\circ} \mathrm{C} ; 0.45 \mu \mathrm{m}$ filtered, supplemented with $8 \mu \mathrm{g} / \mathrm{ml}$ polybrene, aliquoted, and stored at $-70^{\circ} \mathrm{C}$ (Price et al., 1987). The viral concentrate titer was $\sim 10^{6} / \mathrm{ml}$ active virions as determined by infection of NIH 3 T3 cells. Adult male CD1 mice (Charles River, St. Constant, Quebec) were anesthetized with sodium pentobarbital $(120 \mathrm{mg} / \mathrm{kg}$, i.p.), and stereotaxic unilateral injections of 0.4 $\mu \mathrm{l}$ of retrovirus were made into the lateral ventricle at anteroposterior $+4.2 \mathrm{~mm}$ anterior to $\lambda$, lateral $+0.7 \mathrm{~mm}$, and dorsoventral $-2.4 \mathrm{~mm}$ below dura with the skull leveled between $\lambda$ and bregma. After treatments, animals were killed by anesthetic overdose and perfused transcardially with $2 \%$ paraformaldehyde in $0.1 \mathrm{M}$ phosphate buffer, $\mathrm{pH} 7.2$. Brains were postfixed and cryoprotected overnight at $4^{\circ} \mathrm{C}$ in perfusing solution and $25 \%$ sucrose. Serial $60 \mu \mathrm{m}$ coronal cryostat $\left(-19^{\circ} \mathrm{C}\right)$ sections were mounted onto chromium-aluminum subbed slides and reacted at $37^{\circ} \mathrm{C}$ for $6 \mathrm{hr}$ to overnight with X-gal $(1 \mathrm{mg} / \mathrm{ml}$, Promega, Madison, WI) in $0.1 \mathrm{M}$ phosphate buffer, $\mathrm{pH} 7.2$, containing $\mathrm{MgCl}_{2}(2 \mathrm{~mm})$, sodium deoxycholate $(0.01 \%)$, NP40 $(0.02 \%)$, potassium ferrocyanide $(50 \mathrm{~mm})$, and potassium ferricyanide $(50 \mathrm{~mm})$. Slides were rinsed in $3 \%$ dimethylsulfoxide in $0.1 \mathrm{~m}$ phosphate buffer, safranin-counterstained, dehydrated, and coverslipped with Permount.

Growth factor infusion. Growth factors were unilaterally infused directly into the lateral ventricle using an osmotic pump (model 1007; Alza, Palo Alto, CA) attached to a 30 gauge cannulae implanted at the retroviral injection coordinates. One day after retrovirus injection, growth factors [mouse EGF, human recombinant basic FGF, mouse 7S nerve growth factor (NGF), human recombinant TGF- $\alpha$; Upstate Biologicals, Lake Placid, NY] were infused for 6 consecutive days at a flow rate of $0.5 \mu \mathrm{l} / \mathrm{hr}$ with an initial intrapump concentration of $33 \mu \mathrm{g} / \mathrm{ml}$. This correlates to an infusion rate of $400 \mathrm{ng} / \mathrm{d}$. The vehicle solution was $0.9 \%$ saline containing $1 \mathrm{mg} / \mathrm{ml}$ mouse serum albumin (Sigma, St. Louis, MO). Vehicle controls were always performed in parallel with each growth factor infusion experiment to control for baseline interexperimental variability.

Isolation of spheres in vitro. After $6 \mathrm{~d}$ of intraventricular growth factor $(400 \mathrm{ng} / \mathrm{d})$ or vehicle infusion, adult mice were killed by cervical disloca- tion, and brains were excised. Approximately $1 \mathrm{~mm}$ of tissue surrounding the entire lateral ventricle ipsilateral to the infusion cannula was dissected out. Cells were dissociated enzymatically and cultured in the presence of EGF $(20 \mathrm{ng} / \mathrm{ml}$ ), as described previously (Reynolds and Weiss, 1992). After 8-11 d in vitro, the total number of spheres formed was counted for each hemisphere.

$\left[{ }^{3} H\right]$ thy labeling and detection. On the sixth day of EGF infusion, mice were injected every $3 \mathrm{hr}$ for $15 \mathrm{hr}$ with ${ }^{3} \mathrm{H}$-thy $(3 \mu \mathrm{Ci} / \mathrm{gm}$, specific activity $45 \mathrm{Ci} / \mathrm{mmol}$, i.p.; Amersham, Buckinghamshire, UK). One hour after the final injection, mice were killed and processed as for retroviral detection, except that brains were sectioned serially at $6 \mu \mathrm{m}$. Sections were subsequently defatted and processed for autoradiography by dipping in liquid emulsion (Kodak NTB-2 nuclear track emulsion). Slides were stored in the dark at $4^{\circ} \mathrm{C}$ for 4 weeks, developed using Kodak D-19, and fixed in $25 \%$ sodium thiosulfate. Cells were considered to be labeled if the silver grain count was fivefold above background levels.

$B r d U$ labeling and detection. On the sixth day of infusion, mice were injected with BrdU (Sigma) $(120 \mathrm{mg} / \mathrm{kg}$, i.p.) every $3 \mathrm{hr}$ for $15 \mathrm{hr}$ and killed $1 \mathrm{hr}$ after the final injection. Animals were killed, and brains were processed as for immunohistochemistry. Sections were treated initially with $1 \mathrm{M} \mathrm{HCl}$ for $30 \mathrm{~min}$ at $65^{\circ} \mathrm{C}$ to denature cellular DNA. Rat anti-BrdU (1:100; Seralab, London, UK), fluorescein isothiocyanate-conjugated donkey anti-rat, and biotinylated-donkey anti-rat (Jackson, West Grove, PA) with streptavidin-Texas red or streptavidin-CY3 (Sigma) were used for BrdU staining.

Immunohistochemistry. Animals were killed by anesthetic overdose and perfused transcardially with $4 \%$ paraformaldehyde and $0.4 \%$ picric acid in $0.16 \mathrm{M}$ phosphate buffer, $\mathrm{pH} 6.9$ (Zamboni and de Martino, 1967). Brains were postfixed in the perfusing solution for $90 \mathrm{~min}$ at $4^{\circ} \mathrm{C}$ and then cryoprotected for at least $24 \mathrm{hr}$ in $10 \%$ sucrose in $0.1 \mathrm{M}$ phosphate buffer, $\mathrm{pH}$ 7.2. Serial $14 \mu \mathrm{m}$ coronal cryosections $\left(-19^{\circ} \mathrm{C}\right)$ were mounted directly onto chromium-aluminum subbed slides. Sheep anti-EGF receptor (1:50; BioDesign, Carmel, NY), mouse anti-S100 $\beta$ (1:500; Sigma), mouse antiNeuN (1:50; provided by R. Mullen, University of Utah, Salt Lake City, UT) (Mullen ct al., 1992), mouse anti-Rip (1:2; provided by S. Hockfield, Yale University, New Haven, CT) (Friedman et al., 1989), and rabbit anti-nestin (1:1000; provided by R. McKay, LMB/NIND National Institutes of Health, Bethesda, MD) (Hockfield and McKay, 1985; Lendahl et al., 1990) were used with species-specific biotinylated secondary antibodies (Jackson) and streptavidin-CY3 (Sigma) for single-stain immunohistochemistry. Double stains were performed sequentially with speciesspecific biotinylated and fluorescein isothiocyanate-conjugated second aries (Jackson) and streptavidin-Texas red (Sigma). Specificity of immunostaining was confirmed by the absence of detectable fluorescence in sections processed after omitting the primary antibodies.

Statistical analyses. The numbers of retrovirally labeled cells were analyzed using ANOVA and Newman-Keuls post hoc tests $(p<0.05)$. All other experiments were analyzed using Student's $t$ tests $(p<0.05)$.

\section{RESULTS}

\section{Modulation of the constitutively proliferating subependymal progenitor population}

The lateral ventricle subependyma is made up of at least two kinetically distinct neural precursor cell populations: a constitutively proliferating progenitor cell population and a relativcly quiescent stem cell population (Morshead et al., 1994). To study the effects of exogenous growth factors on the constitutively proliferating subependymal population in vivo, a limited number of these actively proliferating cells were infected with a replication-deficient retrovirus containing a $l a c Z$ reporter gene to label without dilution all subsequent progeny of the originally infected proliferating cells (Price et al., 1987; Miller et al., 1990; Hajihosseini et al., 1993; Roe et al., 1993). One day after injection of retrovirus into the adult mouse lateral ventricle, an average of $9.6 \pm 1.5(n=9) \mathrm{LacZ}^{+}$cells were observed in the subependymal layer surrounding the forebrain lateral ventricle ipsilateral to the injection site (counted from the rostral tip of the lateral ventricle extending caudally to the rostral portion of the third ventricle). Seven days after retrovirus injection, the total number of LacZ ${ }^{\prime}$ cells in the lateral ventricle subependyma decreased significantly 


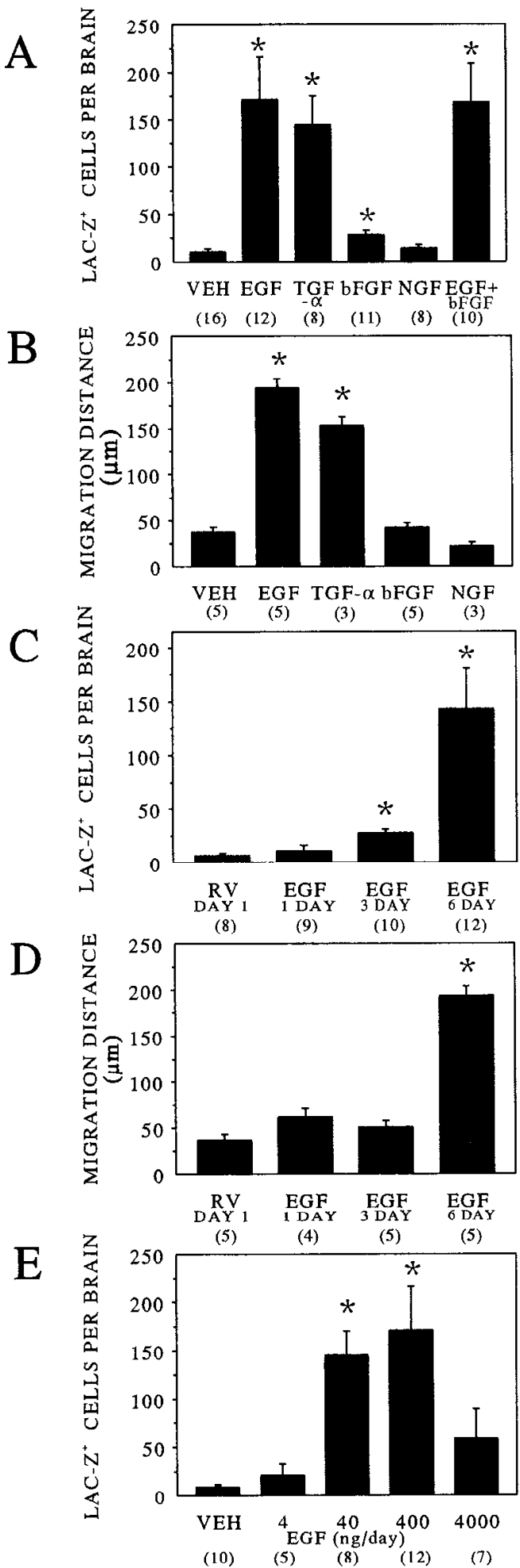

Figure 1. In vivo growth factor modulation of retrovirally labeled $\mathrm{LacZ}^{+}$ subependymal cells. $A$, Growth factor effect on the number of $\mathrm{LacZ}^{+}$cells in the lateral ventricle. $B$, Growth factor effect on the radial distance away from the lateral ventricle walls of $\mathrm{LacZ}^{+}$cells. $C$, Time course for the EGF-induced increase in the number of $\mathrm{LacZ}^{+}$cells. $D$, Time course for the EGF-induced migration of $\mathrm{LacZ}^{+}$cells. $E$, Dose-response relationship for the EGFinduced increase in the number of $\operatorname{Lac} Z^{\prime}$ cells. Retrovirus $(R V)$ was injected on day 0 , and growth factors were infused $(A, B, E)$ on days 1 through 7; EGF was infused $(C, D)$ for 1,3 , and 6 days starting on day 1 . Numbers in parentheses indicate the number of animals per treatment group. $\mathrm{LacZ}^{+}$cells were counted from the rostral tip of the lateral ventricle caudally to the to $3.7 \pm 1.0(n=6 ; t=2.91, p<0.05)$. This normally occurring decrease in the lateral ventricle retrovirally labeled population is the result of cell death and the rostral migration of subependymal cells to the olfactory bulb (Morshead and van der Kooy, 1992; Corotto et al., 1993; Lois and Alvarez-Buylla, 1994). Intraventricular infusion of EGF or TGF- $\alpha$ for 6 consecutive days resulted in 18- and 14-fold increases, respectively, in the total number of retrovirally labeled cells relative to vehicle-infused controls (Figs. $1 A, 2 A, B)$ and in their migration away from the walls of the lateral ventricle into adjacent normal brain parenchyma (Fig. $1 B, 2 A, B$ ). The maximum migration of labeled cells after EGF treatment was $\sim 400 \mu \mathrm{m}$, with no $\mathrm{LacZ}^{+}$cells observed in the contralateral hemisphere. Infusion of vehicle controls alone had no significant effect on the total number or location of labeled subependymal cclls relative to untreated control animals (not shown). These observed effects of EGF were found to be both time- and dosedependent (Fig. $1 C-E$ ). Basic FGF resulted in a 2.4-fold increase in the total number of retrovirally labeled cells but no change in their location relative to vehicle-infused controls (Fig. 1 $A, B$ ). Simultaneous infusion of EGF and bFGF did not enhance the effects attributable to EGF alone (Fig. $1 A$ ), and NGF alone was without effect (Fig. 1A, B).

In a separate set of experiments, the total number of $\mathrm{LacZ}^{+}$ cells that migrated to the olfactory bulb was quantified. Seven days after retrovirus injection, $6.9 \pm 2.2(n=8) \mathrm{LacZ}^{+}$cells were located in the olfactory bulb in vehicle-infused animals, whereas in EGF-infused animals only $0.7 \pm 0.5 \mathrm{LacZ}^{+}$olfactory bulb cells were found ( $n=10$; significantly different from vehicle control, $t=3.21, p<0.05)$. 'Thus, EGF seems to arrest the normal migration of $\mathrm{LacZ}^{+}$cells toward the olfactory bulb and to redirect labeled cells into adjacent brain parenchyma. Simple redirection of subependymal cells that normally migrate to the olfactory bulb, however, cannot fully account for the effects of EGF, because the total $\mathrm{LacZ}^{+}$(lateral ventricle and olfactory bulb) cell population in vehicle-infused animals represents only $8.4 \%$ of the total number of labeled cells recovered after EGF treatment.

\section{Modulation of the relatively quiescent subependymal stem cell population}

The in vivo adult source for in vitro EGF-responsive neural stem cells (Reynolds and Weiss, 1992) is a relatively quiescent cell population residing in the forebrain lateral ventricle subependyma (Morshead et al., 1994). To test the effects of growth factors on this relatively quiescent subependymal stem cell population in vivo, we assessed the effect of intraventricular growth factor infusion on the subsequent isolation of in vitro EGF-responsive neural stem cells. EGF, bFGF, or vehicle was infused into the lateral ventricle of adult mice for $6 \mathrm{~d}$. Subsequently, the ipsilateral subependyma was dissected out, and the number of in vitro EGFgenerated spheres, which are the clonal derivatives of relatively quiescent subependymal stem cells, was assessed (Reynolds and Weiss, 1992; Morshead et al., 1994). In vivo pretreatment of animals for $6 \mathrm{~d}$ with EGF resulted in a $370 \%$ increase in the generation of spheres in vitro $(272 \pm 40$ spheres/hemisphere, $n=9$ ) relative to vehicle-infused controls (73 \pm 7 spheres/

\section{$\leftarrow$}

rostral portion of the third ventricle. Statistical analysis by ANOVA followed by Newman-Keuls multiple comparison tests $(p<0.05) . A, B, E$ : *, Significantly different from the number of $\mathrm{LacZ}^{+}$cells in vehicle-infused controls. $C, D$ : *, Significantly different from the number of $\mathrm{LacZ}^{+}$cells in noninfused controls at the time of growth factor infusion initiation. 

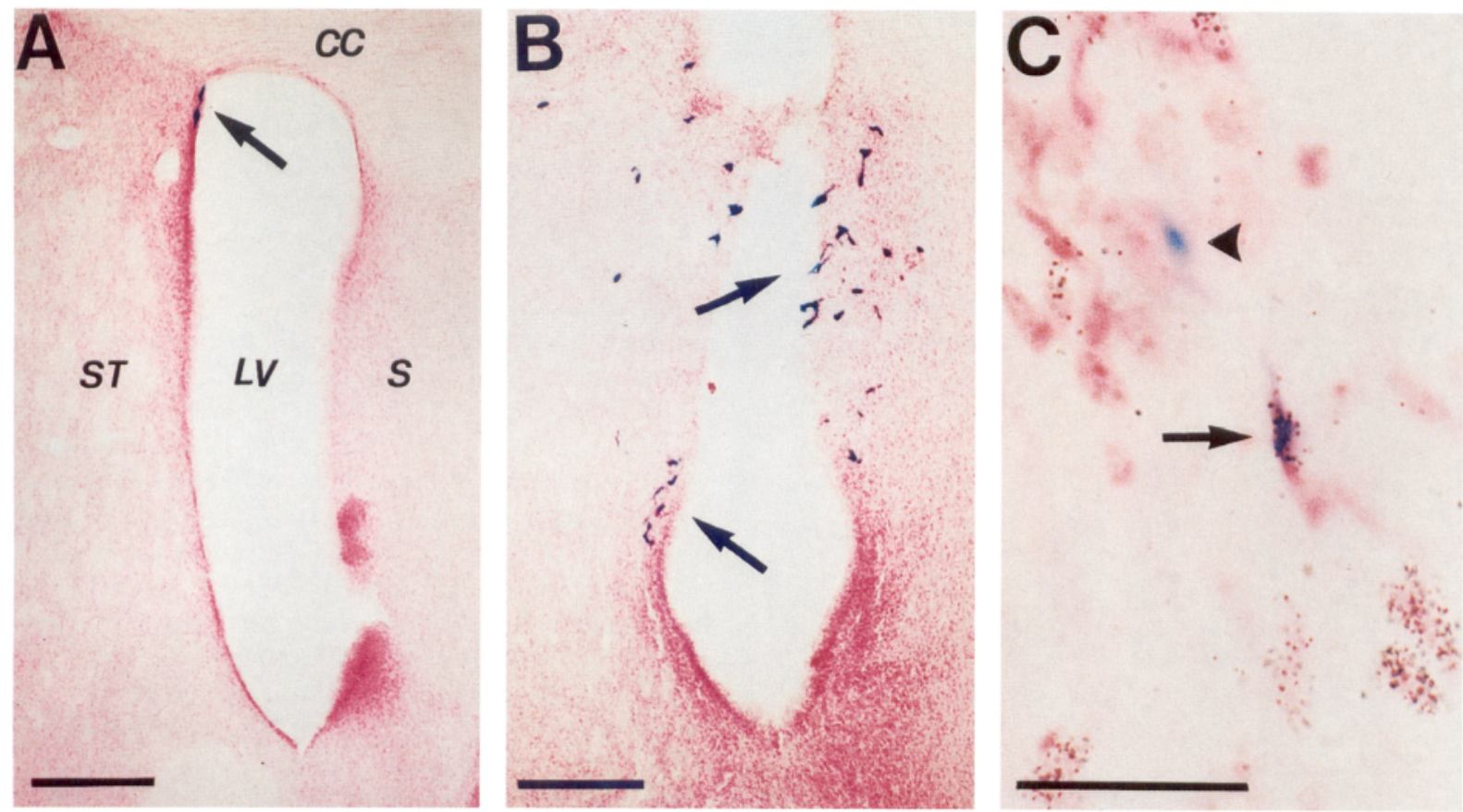

Figure 2. Effect of EGF infusion on the location and proliferation of retrovirally labeled subependymal cells. $A-C$, Retrovirus was injected on day 0 , and EGF was infused on days 1 through 7. $C,\left[{ }^{3} \mathrm{H}\right]$ thy was injected every $3 \mathrm{hr}$ for $15 \mathrm{hr}$ on day 7 . Representative example of LacZ ${ }^{+}$cells (arrows) in vehicle-infused control $(A)$ and after $6 \mathrm{~d}$ of EGF infusion $(B)$ in a $60 \mu \mathrm{m}$ coronal forebrain section. $L V$, Lateral ventricle; $S T$, striatum; $C C$, corpus callosum; $S$, septum (all low-power photomicrographs throughout this article are oriented identically). $C$, Representative example of a $\left.{ }^{3} \mathrm{H}\right]$ thy and LacZ ${ }^{+}$ double-labeled cell (arrow) and a LacZ ${ }^{+}$single-labeled cell (arrowhead). Cells were considered $\left[{ }^{3} \mathrm{H}\right]$ thy-labeled if more than five grains were counted over the cell nuclei. Background counts were determined to be less than one grain per cell. Scale bars: $A, B, 200 \mu \mathrm{m} ; C, 25 \mu \mathrm{m}$.

hemisphere, $n=8 ; t=4.618, p<0.05$ ). Similar in vivo bFGF pretreatment of animals resulted in a $49 \%$ increase in the total number of in vitro spheres isolated in EGF $(227 \pm 29$ spheres/ hemisphere, $n=6)$ relative to vehicle-infused controls $(152 \pm 20$ spheres/hemisphere, $n=6 ; t=4.662, p<0.05)$. These results suggest that in addition to the observed effects on constitutively proliferating subependymal progenitor cells, both EGF and bFGF also seem to induce symmetrical divisions of relatively quiescent subependymal stem cells to effect the expansion of this population in vivo.

\section{EGF-induced proliferation and survival of subependymal precursor cell populations}

The ratio of proliferating to nonproliferating cells in the EGFinduced retrovirally labeled cell population was assessed by $\left[{ }^{3} \mathrm{H}\right]$ thy S-phase labeling on the final day of growth factor infusion. On day 6 of EGF infusion, 167 of $432 \mathrm{LacZ}^{+}$cells analyzed were double-labeled with $\left[{ }^{3} \mathrm{H}\right]$ thy (Fig. $2 \mathrm{C}$ ). This indicates that on the sixth day of growth factor infusion, $38 \%$ of the total EGFexpanded population was proliferating actively. Given that only $2.6 \%$ of the cells proliferating on the sixth day of EGF infusion (labeled with BrdU) were still proliferating $6 \mathrm{~d}$ after EGF withdrawal (labeled with $\left[{ }^{3} \mathrm{H}\right]$ thy; not shown), it is apparent that the observed proliferation in the EGF-expanded population is dependent on the continued presence of EGF and not an inherent trait of these cells or attributable to the action of an independent endogenous factor. It is unlikely that this low level of doublelabeling is the result of the BrdU label diluting out of continuously dividing cells attributable to the greater than 10 -fold excess of readily detectable $\mathrm{BrdU}^{+}$cells relative to $\left[{ }^{3} \mathrm{H}\right]$ thy ${ }^{+}$cells $6 \mathrm{~d}$ after EGF withdrawal. Furthermore, considering that $62 \%$ of the EGFexpanded precursor cell population in vivo is postmitotic (not
Table 1. Expansion of the total number and proliferation of cells surrounding the lateral ventricle immediately after $6 \mathrm{~d}$ of EGF infusion

\begin{tabular}{llccl} 
Group & Total & Proliferating & Astrocytes & Neurons \\
\hline Control & $1658 \pm 161(3)$ & $65 \pm 8(6)$ & $266 \pm 18(3)$ & $1214 \pm 73(3)$ \\
Saline & $1720 \pm 73(3)$ & $78 \pm 9(6)$ & $255 \pm 23(3)$ & $1267 \pm 20(3)$ \\
EGF & $4056 \pm 279^{*}(4)$ & $428 \pm 59^{*}(4)$ & $223 \pm 12(3)$ & $1204 \pm 219(3)$
\end{tabular}

Total and proliferating cell counts were determined with Nissl stain and BrdU immunohistochemistry, respectively. The number of astrocytes and neurons was determined by $\mathrm{S} 100 \beta$ and NeuN immunohistochemistry, respectively. Counts were measured in a minimum of five sections per animal on both sides of the ventricle ipsilateral to the infusion cannula in $0.64 \mathrm{~mm}^{2}$ total tissue area grids at the dorsoventral midpoint of the lateral ventricle in $14 \mu \mathrm{m}$ coronal sections $\sim 200 \mu \mathrm{m}$ caudal to the crossing of the corpus callosum. Numbers in parentheses indicate the total number of animals per group. ${ }^{*}$ Significantly different from control ( $p<0.05, t$ tests).

labeled with $\left[{ }^{3} \mathrm{H}\right]$ thy during a $15 \mathrm{hr}$ period) after $6 \mathrm{~d}$ of EGF infusion, this result suggests that (in addition to a mitogenic action) EGF also may act as a survival factor for the progeny of the constitutively proliferating subependymal cells that normally undergo cell death (Morshead and van der Kooy, 1992). Consistent with the retrovirus and $\left[{ }^{3} \mathrm{H}\right]$ thy results, there was a dramatic increase (Table 1; Fig. $3 A, B$ ) in the number of cells labeled with BrdU on day 6 of EGF infusion relative to the increase on day 6 of vehicle infusions. Basic FGF also resulted in a significant increase $(273.6 \pm 37.4, n=5$ vs $143.2 \pm 11.4, n=5 ; p<0.05)$ in the number of BrdU-labeled cells relative to vehicle controls. The EGF-induced proliferating cells appeared within a spatially restricted zone radiating up to $400 \mu \mathrm{m}$ away from the walls of the lateral ventricle in adjacent normal brain parenchyma (Fig. 3A,B). Accompanying this dramatic increase in the proliferation of cells surrounding the lateral ventricle was a 2.4 -fold increase in the 

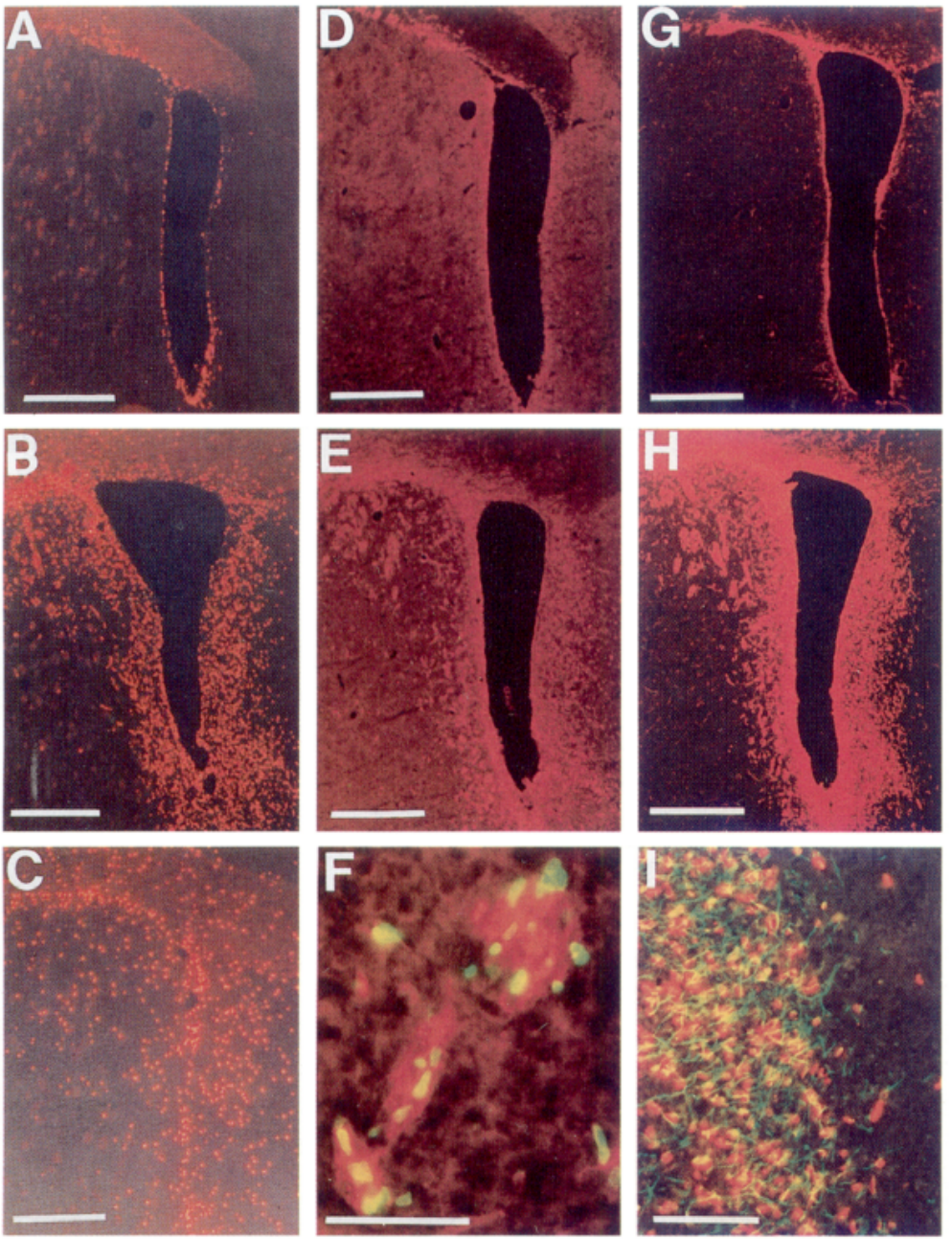
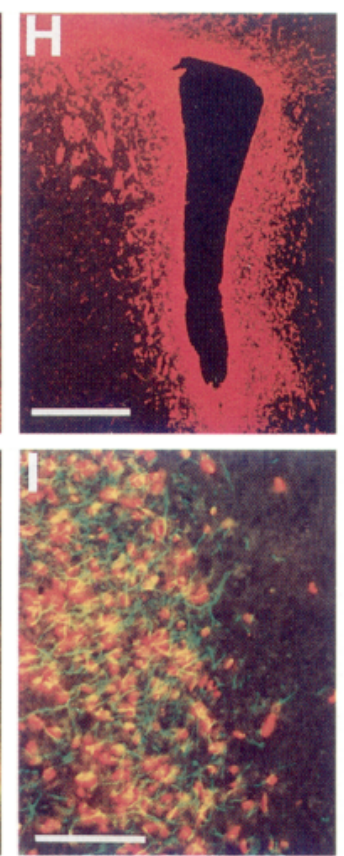

Figure 3. Characterization of the EGF-expanded subependymal cell population on day 6 of EGF infusion. Animals were infused for $6 \mathrm{~d}$ with vehicle $(A, D, G)$ or $\operatorname{EGF}(B, C, E, F, H, I)$. BrdU was injected every $3 \mathrm{hr}$ for $15 \mathrm{hr}$ on the final infusion day. Animals were killed $2 \mathrm{hr}$ after the final BrdU injection and processed for BrdU $(A, B, F, I)$, EGF-receptor $(D-F)$, or nestin $(G-I)$ immunoreactivity. $C$, EGF infusion was terminated after the final BrdU injection, and animals were killed and processed for BrdU immunoreactivity 7 weeks later. $F$, Double-label immunohistochemistry for EGF receptor (red) and BrdU (green) in the dorsomedial striatum on day 6 of EGF infusion. I, Double-label immunohistochemistry for nestin (green) and BrdU (red) radiating away from the medial lateral ventricle wall on day 6 of EGF infusion. Scale bars: $A-E, G, H, 300$ $\mu \mathrm{m} ; F, 100 \mu \mathrm{m} ; I, 50 \mu \mathrm{m}$. total number of cells in this region, as quantified with cresyl violet Nissl staining on day 6 of EGF infusion (Table 1). Similar to the BrdU labeling pattern, the EGF-induced increase in Nissl cells also appeared in a spatially restricted zone surrounding the walls of the lateral ventricle (not shown). Given that only $38 \%$ of the EGF-expanded retrovirally population is labeled with $\left[{ }^{3} \mathrm{H}\right]$ thy on day 6 of EGF infusion, it is presumed that BrdU labeling similarly underestimates the overall magnitude of the EGF-generated population.

\section{Characterization of in vivo EGF-responsive cells}

To ask whether the effects of EGF were attributable to direct actions on EGF-responsive subependymal cells, the spatial distribution of EGF-receptor-bearing cells was determined by immunohistochemistry. Although the fibrous nature of the EGFreceptor staining pattern precluded exact quantification, $6 \mathrm{~d}$ of EGF infusion elicited a dramatic increase and spatial expansion of EGF-receptor expression (compared with control and vehicleinfused EGF-receptor staining pattern, which was restricted to the lateral ventricle subependyma) (Fig. 3D,E). The EGF-receptor staining pattern after EGF infusion essentially overlapped the regions found previously to contain the EGF-induced proliferating population (Fig. $3 A, B$ ). Examination of individual proliferating cells revealed that $>95 \%$ of the $\mathrm{BrdU}^{+}$cells overlapped EGF receptor ${ }^{+}$staining (Fig. $3 F$ ). Thus, EGF seems to exert its effects by directly activating EGF receptors on responsive cells and not through an action on an intermediary cell population. Of course, it remains possible that some of the effects attributed to EGF may be indirect through the release of a secondary, autocrine-acting growth factor.

To assess whether EGF also induces the proliferation of endogenous mature cell populations, the total numbers of astrocytes and neurons surrounding the lateral ventricle were determined. Although $6 \mathrm{~d}$ of EGF infusion induces a dramatic increase in the proliferation of cells surrounding the lateral ventricle, the absolute numbers of S100 $\beta^{+}$astrocytes (Ghandour et al., 1981; Hafidi et al., 1994) and $\mathrm{NeuN}^{+}$neurons (Mullen et al., 1992; Morassutti et al., 1994; Staines et al., 1994) in this region did not change significantly relative to control or vehicle-infused animals (Table 1). This lack of an increase in the astrocytic population surrounding the lateral ventricle clearly indicates that the EGF-induced proliferative response is not the result of a localized gliosis. This is consistent with the absence of induction of glial fibrillary acid protein expression in the periventricular region (not shown). Similarly, there was no dramatic change in the qualitative nature of microglial (MAC-1) or oligodendrocyte (MAG, CNP, O4, Rip) staining patterns after $6 \mathrm{~d}$ of EGF infusion (not shown). The lack of any detectable decreases in either the glial or neuronal cell populations after EGF infusion also indicates that EGF is not acutely cytotoxic for mature cell populations.

Nestin is an intermediate filament protein expressed in neuroepithelial precursor cells (Hockfield and McKay, 1985; Lendahl et al., 1990). In the adult brain, the subependymal region, which 
Table 2. In vivo differentiation of EGF-generated neural precursors 7 weeks after EGF withdrawal

\begin{tabular}{|c|c|c|c|c|c|c|}
\hline \multirow[b]{2}{*}{ Treatment } & \multicolumn{3}{|l|}{ Astrocyte } & \multicolumn{2}{|l|}{ Neuron } & \multirow[b]{2}{*}{$\begin{array}{l}\text { Percentage } \\
\text { double label }\end{array}$} \\
\hline & BrdU & $\begin{array}{l}\mathrm{S} 100 \beta+ \\
\mathrm{BrdU}\end{array}$ & $\begin{array}{l}\text { Percentage } \\
\text { double label }\end{array}$ & BrdU & $\begin{array}{l}\text { NeuN + } \\
\text { BrdU }\end{array}$ & \\
\hline Control (no pump) & $4085 \pm 416$ & $229 \pm 43$ & 5.6 & $4766 \pm 511$ & $12 \pm 2$ & 0.2 \\
\hline Saline (day 6$)^{a}$ & $5307 \pm 756$ & $314 \pm 70$ & 6.4 & $5905 \pm 356$ & $15 \pm 1$ & 0.2 \\
\hline EGF $(\text { day } 6)^{a}$ & $37984 \pm 3288^{*}$ & $340 \pm 120$ & $0.9^{*}$ & $39312 \pm 2422^{*}$ & $148 \pm 56^{*}$ & 0.4 \\
\hline Saline (day 55$)^{a}$ & $245 \pm 72^{*}$ & $160 \pm 50$ & $65.1^{*}$ & $178 \pm 8^{*}$ & $1 \pm 1$ & 0.5 \\
\hline $\mathrm{EGF}(\text { day } 55)^{a}$ & $9786 \pm 197^{*}$ & $2876 \pm 320^{*}$ & $29.4^{*}$ & $9817 \perp 204^{*}$ & $298 \pm 24^{*}$ & $3.0^{*}$ \\
\hline
\end{tabular}

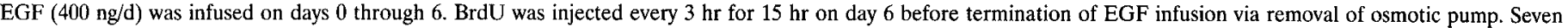

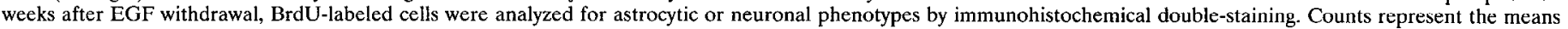

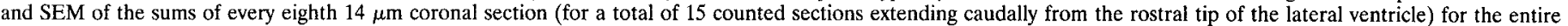
hemisphere ipsilateral to the infusion cannulae from three separate animals per treatment group. ${ }^{*}$ Significantly different from control $(p<0.05, t$ tests).

${ }^{a}$ Number in parentheses indicates number of days postinfusion initiation before animal was killed.

contains neural precursor cells, recently was shown to stain for nestin (Morshead et al., 1994). Examination of nestin expression immediately after $6 \mathrm{~d}$ of EGF infusion revealed a dramatic increase in the total amount and spatial distribution of nestin staining, overlapping the regions previously found to contain the EGF-induced proliferating cells and the increased EGFreceptor expression (Fig. $3 G, H$ ). The filamentous nature of the nestin staining pattern precluded exact quantification; however, examination of individual isolated proliferating cells revealed that $>95 \%$ of the $\mathrm{BrdU}^{+}$cells overlapped nestin ${ }^{+}$fibers (Fig. 3I). This suggests that the in vivo EGF-responsive cells represent undifferentiated neural precursor cells, which may have the capacity to differentiate into mature CNS cell types in situ (Corotto et al., 1993; Lois and Alvarez-Buylla, 1993, 1994; Morshead et al., 1994).

\section{In vivo differentiative potential of EGF-responsive cells}

In the avian brain, newly generated germinal zone cells require a minimum of 3-6 weeks to mature into detectable neurons (Nottebohm and Alvarez-Buylla, 1993). To determine the differentiative capacity of the EGF-generated $\mathrm{BrdU}^{+}$precursor cells in vivo, EGF was infused for $6 \mathrm{~d}$, BrdU was injected on the final day of EGF infusion, and infusion was terminated after the final BrdU injection. The animals were then allowed to survive for 7 additional weeks before characterization of the $\mathrm{BrdU}^{+}$cell phenotypes. Consistent with the observation that acute EGF infusion had no effect on the total number of astrocytes surrounding the lateral ventricle (Table 1 ), the total number of $\mathrm{BrdU}^{+}$cells that double-stained for the astrocyte marker S100 $\beta$ was not significantly different on the sixth day of EGF infusion relative to control or vehicle-infused animals (Table 2). A constant number of $\mathrm{BrdU}^{+} \mathrm{S} 100 \beta^{+}$double-labeled cells in untreated control, vehicle-, and acutely EGF-treated animals were distributed randomly and represent the basal level of normal mature astrocyte turnover (Altman, 1969). In vehicle-infused animals, the 7 week postinfusion survival period resulted in a decrease in the total number of $\mathrm{BrdU}^{+}$cells but no change in the total number of $\mathrm{BrdU}^{+} \mathrm{S} 100 \beta^{+}$double-labeled cells (Table 2 ). This maintenance of the total number of double-labeled $\mathrm{BrdU}^{+} \mathrm{S} 100 \beta^{+}$cells suggests that the $\mathrm{BrdU}^{+}$-labeled mature astrocyte population does not expand significantly over this time period.

In control and vehicle-infused animals, $0.2 \%$ of the $\mathrm{BrdU}^{+}$cells were $\mathrm{NeuN}^{+}$(Table 2). Given the postmitotic nature of neurons, these double-labeled cells likely represent the true nonspecific overlap of separate cells in this type of analysis (some minor cellular overlap seems probable considering the $14 \mu \mathrm{m}$ section thickness and the $<10 \mu \mathrm{m}$ cell body diameters). In animals killed immediately after $6 \mathrm{~d}$ of EGF infusion, there was a significant increase in the total number of $\mathrm{BrdU}^{+} \mathrm{NeuN}^{+}$cells but no increase in the percentage of $\mathrm{BrdU}^{+}$cells that were double-labeled, relative to untreated control animals (Table 2 ). These cells also represent the nonspecific overlap of separate cells, with the increase in the total number of double-labeled cells simply reflecting the increased density of $\mathrm{BrdU}^{+}$cells surrounding the lateral ventricles. These results are consistent with the observation that EGF infusion for $6 \mathrm{~d}$ had no effect on the total number of neurons surrounding the lateral ventricles (Table 1).

In FGF-infused animals, 7 weeks after EGF withdrawal, $\sim 25 \%$ of the cells induced to proliferate after $6 \mathrm{~d}$ of EGF infusion were still detectable (Table 2; Fig. $3 C$ ). The majority of these $\mathrm{BrdU}^{+}$ cells was found to be localized to the broad regions surrounding the lateral ventricles. During the 7 week period after EGF withdrawal, these $\mathrm{BrdU}^{+}$cells increased their maximal distance away from the walls of the lateral ventricle from $\sim 400 \mu \mathrm{m}$ to $700 \mu \mathrm{m}$. The mcchanism underlying the $75 \%$ loss of the EGF-generated $\mathrm{BrdU}^{+}$cell population over 7 weeks is not known, but it may be the result of cell death, migration of these cells to distant CNS regions, or their continued proliferation and thus the diluting out of the BrdU label in these cells. Coincident with this decrease in the total number of EGF-generated $\mathrm{BrdU}^{+}$cells was a dramatic increase in the total number of $\mathrm{BrdU}^{+} \mathrm{S} 100 \beta^{+}$double-labeled cells, and a smaller but significant increase in the total number of $\mathrm{BrdU}^{+} \mathrm{NeuN}^{+}$double-labeled cells (Table 2; Fig. 4). Of the $\mathrm{BrdU}^{+}$cells still detectable 7 wecks after EGF withdrawal, 28\% double-labeled for the astrocyte marker $\mathrm{S} 100 \beta$, and $3 \%$ doublelabeled for the neuronal marker NeuN. These analyses were performed caudal to the olfactory bulb and rostral to the hippocampus and thus do not include the adult genesis of new neurons in either of these regions (Kaplan, 1985; Corotto et al., 1993). Numerous $\mathrm{BrdU}^{+} \mathrm{Rip}^{+}$double-labeled cells are also observed 7 weeks after EGF withdrawal (Fig. 4). Rip specifically labels mature oligodendrocyte perikarya and processes (Friedman et al., 1989). Exact quantitation of the actual percentage of oligodendrocytes generated was not possible because of extensive Rip process staining, which restricted counts. All three of the double-labeled cell populations were located up to a maximum distance of $700 \mu \mathrm{m}$ away from the lateral ventricle walls, essentially equally divided between the cortex, striatum, and septum.

Because of the $75 \%$ decrease in the density of $\mathrm{BrdU}^{+}$cells 7 weeks after EGF withdrawal, it is highly unlikely that the observed increases in the double-labeled populations are the result of an 

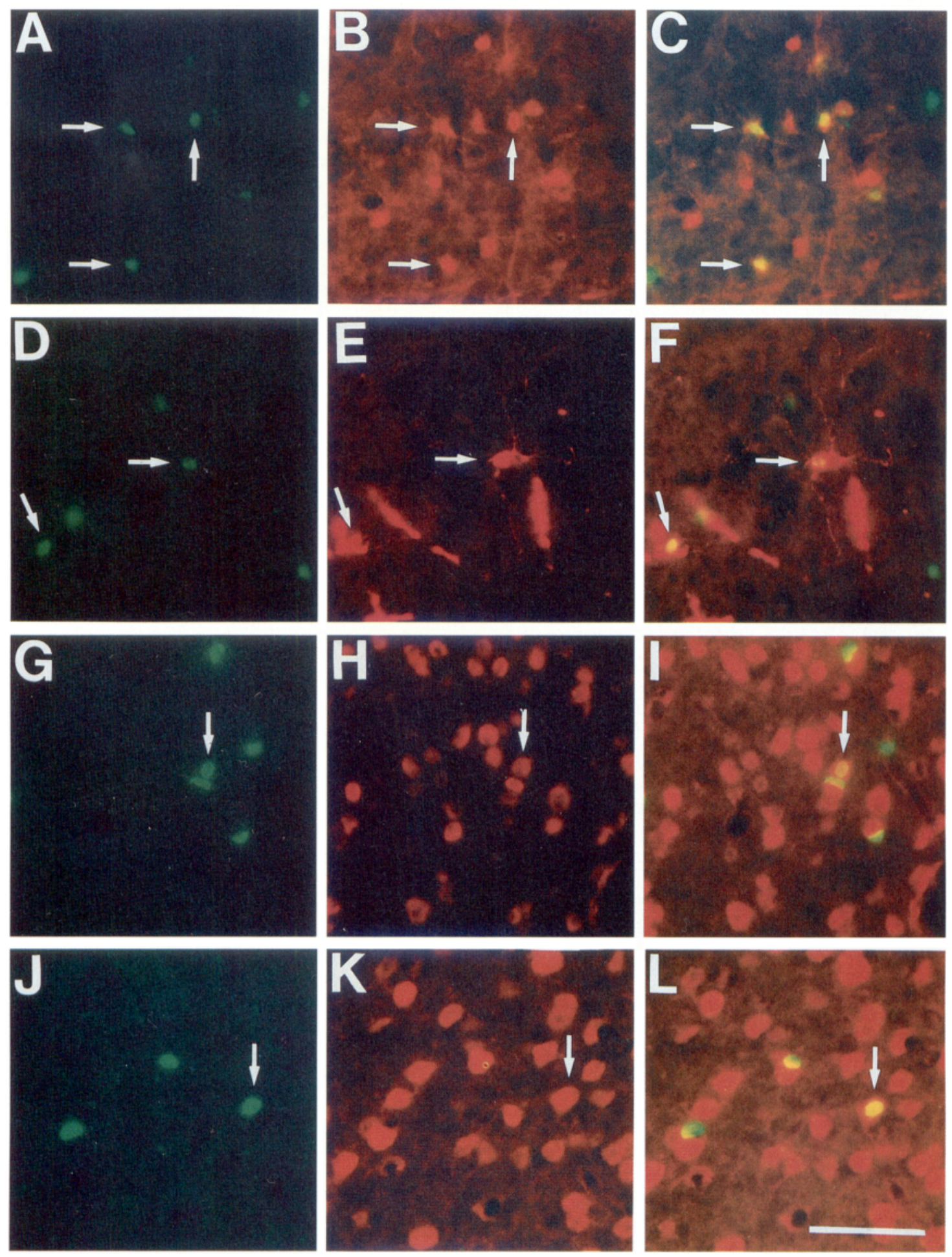

Figure 4. In situ colocalization of $\mathrm{BrdU}^{+}$cells with astrocyte, oligodendrocyte, and neuronal phenotype markers 7 weeks after EGF withdrawal. Animals were infused for $6 \mathrm{~d}$ with EGF, and BrdU was injected every $3 \mathrm{hr}$ for $15 \mathrm{hr}$ on the final infusion day. EGF infusion was terminated immediately after the final BrdU injection, and animals were killed and processed for immunohistochemistry 7 weeks later. $A, D, G, J$, BrdU immunoreactivity (green). $B, \mathrm{~S} 100 \beta$ astrocyte staining $(r e d)$ in the same field as for $A$. $C$, Double-labeling for BrdU and $\mathrm{S} 100 \beta$ displayed by double-exposure of the images shown in $A$ and B. E, Rip oligodendrocyte staining (red) in the same field as for D. F, Double-labeling for BrdU and Rip displayed by double-exposure of the images shown in $D$ and $E . H, K$, NeuN neuron staining (red) in the same field as $G$ and $J$, respectively. $I$, $L$, Double-labeling for BrdU and NeuN displayed by double-exposure of the images shown in $G, J$ and $H, K$, respectively. Arrows represent double-labeled cells (yellow in $C, F, I$, and $L$ ). Scale bar (shown in $L$ ): $50 \mu \mathrm{m}$.

increase in the nonspecific overlap of separate cells. Rather, we conclude that these late-appearing double-labeled cells represent new astrocytes, oligodendrocytes, and neurons, which have ma- tured from undifferentiated EGF-responsive precursor cells that were expanded out of the adult subependyma. This is consistent with a dramatic loss of nestin expression (and rerestriction of 
nestin staining to the periventricular region; not shown) in animals allowed to survive for 7 weeks after growth factor withdrawal. The preferential differentiation of EGF-responsive subependymal precursor cells into glia rather than neurons is consistent with previous studies of the differentiation of neural precursor cells, and this difference may reflect an inherent default pathway for differentiation (Temple, 1989; Cattaneo and McKay, 1990; Murphy et al., 1990; Reynolds and Weiss, 1992; Kilpatrick and Bartlett, 1993). Correcting for false positives and for the possibility of counting the same cell in adjacent sections (Abercrombie, 1946), and considering that our counts are based on the sums of one out of every eight sections (encompassing approximately one half of the total rostral-caudal length of the lateral ventricle), we estimate that $\sim 4 \times 10^{5}$ new precursor cells, $2.8 \times$ $10^{4}$ new astrocytes, and $2.5 \times 10^{3}$ new neurons per hemisphere were generated by $6 \mathrm{~d}$ of EGF infusion and a 7 week postinfusion period. These approximations presumably underestimate the true magnitude of the EGF effect, considering that only one third of the EGF-expanded precursor population is mitotically active on the day of BrdU injection (Fig. $2 C$ ).

\section{DISCUSSION}

EGF infusion into the adult mammalian brain results in a dramatic increase in the endogenous subependymal neural precursor cell populations and their migration away from the lateral ventricle walls into adjacent normal brain parenchyma where, after growth factor withdrawal, they can differentiate into new CNS neurons and glia.

It is apparent that the EGF-responsive cells are derived specifically from the lateral ventricle subependymal region. Retrovirally labeled subependymal cells, $1 \mathrm{~d}$ after retrovirus injection (at the time point when growth factor infusion was initiated), were always found to reside within $50 \mu \mathrm{m}$ of the lateral ventricle wall, whereas after $6 \mathrm{~d}$ of EGF infusion retrovirally labeled cells were recovered up to a maximum distance of $400 \mu \mathrm{m}$ away from the ventricle wall. Furthermore, after unilateral infusion of EGF, the increases in cell density, proliferation, and EGF-receptor and nestin expression occur in an identical time-dependent manner. These increases were observed bilaterally but always specifically localized to the regions surrounding the lateral ventricles, with no induction of proliferation in either the third or fourth ventricles after EGF infusion. In separate experiments, in which EGF was infused directly into the lateral striatum rather than the lateral ventricle, identical proliferative effects were noted surrounding the ipsilateral lateral ventricle, with no increased proliferation relative to vehicle controls in the region proximal to the striatally implanted cannulae (unpublished results). Thus, it is clear that EGF does not induce the proliferation of endogenous resident striatal cell population(s), but rather that EGF acts directly through the EGF receptor to induce the proliferation, survival, and migration away from the forebrain lateral ventricle walls of undifferentiated subependymal precursor cells.

The observed dramatic increase in the total number of proliferating cells (BrdU) and the overall increased density of precursor cells (Nissl) surrounding the adult subependyma after FGF infusion suggests that F,GF may exert its effects by acting as a mitogen for subependymal cells as well as a survival factor for the normally dying postmitotic progeny of these proliferating cells (Morshead and van der Kooy, 1992); however, a more comprehensive understanding of the exact nature of the effects of EGF on subependymal cells in vivo awaits a more detailed investigation.
The adult subependyma consists of at least two kinetically distinct cell populations: a relatively quiescent stem cell population and a constitutively proliferating progenitor cell population (Morshead et al., 1994). The postmitotic fate of the constitutively proliferating cell population has been determined to be cell death or neuronal differentiation after migration to the olfactory bulb (Morshead and van der Kooy, 1992; Lois and Alvarez-Buylla, 1994). Persistence of the constitutively proliferating cell population throughout the lifetime of the animal suggests that a relatively quiescent stem cell must exist to proliferate infrequently to self-renew and to repopulate the constitutively proliferating population that is continuously being depleted. 'l'he present results suggest that exogenous EGF exerts a mitogenic effect on both the relatively quiescent stcm and the constitutively proliferating progenitor subependymal cell populations in vivo. First, the increased number of in vitro EGF-responsive spheres [the clonal derivatives of the relatively quiescent subependymal stem cell population (Morshead et al., 1994)] after in vivo EGF infusion implies that EGF must induce at least some symmetrical cell divisions within the stem cell population. Second, given that the magnitude of the overall increase (3.7-fold) in the number of in vitro stem cells cannot account for the overall increase (6.7- to 7.2-fold; Table 2 ) in the EGF-induced $\mathrm{BrdU}^{+}$cell populations after $6 \mathrm{~d}$ of EGF infusion, EGF must also induce symmetric divisions within the constitutively proliferating (progenitor cell) population, independent of the expansion of the stem cell population. These symmetrically dividing constitutively proliferating cells would thus be equivalent to the transit amplifying cells hypothesized to exist in other tissues containing stem and progenitor cells (Hall and Watt, 1989; Potten and Loeffler, 1990). Basic FGF also may act on both the relatively quiescent stem and the constitutively proliferating progenitor subependymal cell populations in vivo, because $6 \mathrm{~d}$ of bFGF infusion also resulted in significant (albeit smaller) increases in both in vitro EGFdependent sphere formation (0.5-fold) and in vivo $\mathrm{BrdU}^{+}$cells (2.4-fold).

EGF is also proposed to be a migration factor for subependymal cells: EGF seems to arrest the normal migration of constitutively proliferating cells to the olfactory bulb and to promote the migration of subependymal precursor cells away from the lateral ventricle walls into adjacent cortex, striatum, and septum. It is important to note that simple redirection of olfactory bulb-bound cells can account for only $8.4 \%$ of the total EGF-expanded, retrovirally labeled population. The guidance cues that promote the normal migration of surviving subependymal cells toward the olfactory bulb have not yet been identified definitively; however, neural cell adhesion molecule (NCAM) has been shown to be expressed on the cells along this rostral migratory route (Rousselot et al., 1995), and NCAM ( $-/-)$ mice show selective defects in cell migration to the olfactory bulb (Tomasiewicz et al., 1993; Cremer et al., 1994). In these mice, subependymal cells accumulate primarily along the lateral wall and in the dorsolateral corner of the lateral ventricle with no apparent accompanying migration into adjacent brain regions, and there are minimal effects on subependymal cells along the medial wall of the lateral ventricle. The distinctly different patterns of subependymal cell accumulation in NCAM $(-/-)$ and EGF-treated mice (extensive migration of subependymal cells into adjacent parenchyma equally on all sides of the ventricle) demonstrate that the effects of EGF are distinct from the modulation of NCAM on neural progenitor cell surfaces. 
There is optimism for a potential therapeutic applications of this work, given that the constitutively proliferating forebrain subependymal cells found in the adult mouse have also been reported to be present in the rat, dog, monkey, and human (Lewis, 1968; Blakemore and Jolly, 1972; Privat and Leblond, 1972; Rakic and Kornack, 1993; Kirschenbaum et al., 1994). It remains to be seen whether the neurons generated from endogenous adult neural precursor cells in the subependyma can be directed specifically to neuron-deficient CNS regions and whether these de novo-generated neurons are able to make synaptic connections that impart significant gains of function. In conclusion, in situ growth factor modulation of endogenous CNS precursor cells represents a novel model for the study of neural development in the adult mammalian brain and may provide unique insights to help achieve adult replacement of neurons and/or glia lost to disease or trauma, without the necessity for transplantation.

\section{REFERENCES}

Abercrombie M (1946) Estimation of nuclear populations from microtome sections. Anat Rec 94:239-247.

Altman J (1969) Autoradiographic and histological studies of postnatal neurogenesis. 3. Dating the time of production and onset of differentiation of cerebellar microneurons in rats. J Comp Neurol 136:269-293.

Anchan RM, Reh TA, Angello J, Balliet A, Walker M (1991) EGF and TGF-alpha stimulate retinal neuroepithelial cell proliferation in vitro. Neuron 6:923-936.

Blakemore WF, Jolly RD (1972) The subependymal plate and associated ependyma in the dog. An ultrastructural study. J Neurocytol 1:69-84.

Cattaneo E, McKay R (1990) Proliferation and differentiation of neuronal stem cells regulated by nerve growth factor. Nature 347:762-765.

Corotto FS, Henegar JA, Maruniak JA (1993) Neurogenesis persists in the subependymal layer of the adult mouse brain. Neurosci Lett 149:111-114.

Craig CG, Morshead CM, Roach A, van der Kooy D (1994) Fvidence for a relatively quiescent stem cell in the subependyma of the adult mammalian forebrain. J Cell Biochem 18[Suppl]:176.

Cremer II, Lange R, Christoph A, Plomann M, Vopper G, Rocs J, Brown R, Baldwin S, Kraemer P, Scheff S, Barthels D, Rajewsky K, Wille W (1994) Inactivation of the N-cam gene in mice results in size reduction of the olfactory bulb and deficits in spatial learning. Nature $367: 455-459$.

Davis AA, Temple S (1994) A self-renewing multipotential stem cell in embryonic rat cerebral cortex. Nature 372:263-266.

Friedman B, Hockfield S, Black JA, Woodruff KA, Waxman SG (1989) In situ demonstration of mature oligodendrocytes and their processes: an immunohistochemical study with a new monoclonal antibody, Rip. Glia 2:380-390.

Galileo DS, Gray GE, Owens GC, Majors J, Sanes JR (1990) Neurons and glia arise from a common progenitor in chicken optic tectum: demonstration with two retroviruses and cell type-specific antibodies. Proc Natl Acad Sci USA 87:458-462.

Gensburger C, Labourdette G, Sensenbrenner M (1987) Brain basic fibroblast growth factor stimulates the proliferation of rat neuronal precursor cells in vitro. FEBS Lett 217:1-5.

Ghandour MS, Langley OK, Labourdette G (1981) Specific and artefactual cellular localizations of $\$ 100$ protein: an astrocyte marker in rat cerebellum. Dev Neurosci 4:66-78.

Grove EA, Williams BP, Li DQ, Hajihosseini M, Friedrich A, Price J (1993) Multiple restricted lineages in the embryonic rat cerebral cortex. Development 117:553-561.

Hafidi A, Sanes DH, Hillman DE, Kedeshian P (1994) Structural and molecular heterogeneity of astrocytes and oligodendrocytes in the gerbil lateral superior olive. Neuroscience 60:503-519.

Hajihosseini M, Iavachev L, Price J (1993) Evidence that retroviruses integrate into post-replication host DNA. EMBO J 12:4969-4974.

Hall PA, Watt FM (1989) Stem cells: the generation and maintenance of cellular diversity. Development 106:619-633.

Hockfield S, McKay RD (1985) Identification of major cell classes in the developing mammalian nervous system. J Neurosci 5:3310-3328.
Kaplan MS (1985) Formation and turnover of neurons in young and senescent animals: an electromicroscopic and morphometric analysis. Ann NY Acad Sci 457:173-192.

Kilpatrick TJ, Bartlett PF (1993) Cloning and growth of multipotential neural precursors: requirements for proliferation and differentiation. Neuron 10:255-265.

Kirschenbaum B, Nedergaard M, Preuss A, Barami K, Fraser RAR, Goldman SA (1994) In vitro neuronal production and differentiation by precursor cells derived from the adult human forebrain. Cereb Cortex 6:576-589.

Krushel LA, Johnston JG, Fishell G, Tibshirani R, van der Kooy D (1993) Spatially localized neuronal cell lineages in the developing mammalian forebrain. Neuroscience 53:1035-1047.

Lendahl U, Zimmerman LB, McKay RD (1990) CNS stem cells express a new class of intermediate filament protein. Cell 60:585 593 .

Levison SW, Goldman JE (1993a) Both oligodendrocytes and astrocytes develop from progenitors in the subventricular zone of postnatal rat forebrain. Neuron 10:201-212.

Levison SW, Goldman JE (1993b) The migrational patterns and developmental fates of glial precursors in the rat subventricular zone are temporally regulated. Development 119:611-622.

Lewis PD (1968) A qualitative study of cell proliferation in the subependymal layer of the adult rat brain. Exp Neurol 20:203-207.

Lois C, Alvarez-Buylla A (1993) Proliferating subventricular cells in the adult mammalian forebrain can differentiate into neurons and glia. Proc Natl Acad Sci USA 9():2074-2077.

Lois C, Alvarez-Buylla A (1994) Long-distance neuronal migration in the adult mammalian brain. Science 264:1 145-1148.

Luskin MB, McDermott K (1994) Divergent lineages for oligodendrocytes and astrocytes originating in the neonatal forebrain subventricular zone. Glia 11:211-226.

Luskin MB, Parnavelas JG, Barfield JA (1993) Neurons, astrocytes, and oligodendrocytes of the rat cerebral cortex originate from separate progenitor cells: an ultrastructural analysis of clonally related cells. J Neurosci 13:1730-1750.

Luskin MB, Pearlman AL, Sanes JR (1988) Cell lineage in the cerebral cortex of the mouse studied in vivo and in vitro with a recombinant retrovirus. Neuron 1:635-647.

McConnell SK (1988) Development and decision-making in the mammalian cerebral cortex. Brain Res 472:1-23.

McKay RD (1989) The origins of cellular diversity in the mammalian central nervous system. Cell 58:815-821.

Miller DG, Adam MA, Miller AD (1990) Gene transfer by retrovirus vectors occurs only in cells that are actively replicating at the time of infection. Mol Cell Biol 10:4239-4242.

Morassutti DJ, Staines WA, Magnuson DS, Marshall KC, McBurney MW (1994) Murine embryonal carcinoma-derived neurons survive and mature following transplantation into adult rat striatum. Neuruscience 58:753-763.

Morshead CM, van der Kooy D (1992) Postmitotic death is the fate of constitutively proliferating cells in the subependymal layer of the adult mouse brain. J Neurosci 12:249-256.

Morshead CM, Reynolds BA, Craig CG, McBurney MW, Staines WA. Morassutti D, Weiss S, van der Kooy D (1994) Neural stem cells in the adult mammalian forebrain: a relatively quiescent subpopulation of subependymal cells. Neuron 13:1071-1082.

Mullen RJ, Buck CR, Smith AM (1992) NeuN, a neuronal specific nuclear protein in vertebrates. Development 116:201-211.

Murphy M, Drago J, Bartlett PF (1990) Fibroblast growth factor stimulates the proliferation and differentiation of neural precursor cells in vitro. J Neurosci Res 25:463-475.

Nottebohm F, Alvarez-Buylla A (1993) Neurogenesis and neuronal replacement in adult birds. In: Neuronal cell death and repair (Cuello AC, ed), pp 227-236. New York: Elsevier.

Potten CS, Loeffler M (1990) Stem cells: attributes, cycles, spirals, pitfalls and uncertainties. Lessons for and from the crypt. Development 110:1001 1020 .

Price J, Thurlow L (1988) Cell lineage in the rat cerebral cortex: a study using retroviral-mediated gene transfer. Development 104:473-482.

Price J, Turner D, Cepko C (1987) Lineage analysis in the vertebrate nervous system by retrovirus-mediated gene transfer. Proc Natl Acad Sci USA 84:156-160.

Privat A, Leblond CP (1972) The subependymal layer and neighbouring region in the brain of the young rat. J Comp Neurol 146:277-302. 
Rakic P (1985) Limits of neurogenesis in primates. Science 227:1054-1056

Rakic P, Kornack DR (1993) Constraints on neurogenesis in adult primate brain: an evolutionary advantage? In: Neuronal cell death and repair (Cuello AC, ed), pp 257-266. New York: Elsevier.

Reynolds BA, Weiss S (1992) Generation of neurons and astrocytes from isolated cells of the adult mammalian central nervous system. Science 255:1707-1710.

Reynolds BA, Tetzlaff W, Weiss S (1992) A multipotent EGF-responsive striatal embryonic progenitor cell produces neurons and astrocytes. J Neurosci 12:4565-4574.

Richards LJ, Kilpatrick TJ, Bartlett PF (1992) De novo generation of neuronal cells from the adult mouse brain. Proc Natl Acad Sci USA 89:8591-8595.

Roe TY, Reynolds TC, Yu G, Brown PO (1993) Integration of murine leukemia virus DNA depends on mitosis. EMBO J 12:2099-2108.
Rousselot P, Lois C, Alvarez-Buylla A (1995) Embryonic (PSA) N-CAM reveals chains of migrating neuroblasts between the lateral ventricle and the olfactory bulb of adult mice. J Comp Neurol 351:51-61.

Staines WA, Morassutti DJ, Reuhl KR, Ally AI, McBurney MW (1994) Neurons derived from P19 embryonic carcinoma cells have varied morphologies and neurotransmitters. Neuroscience 58:735-751.

Temple S (1989) Division and differentiation of isolated CNS blast cells in microculture. Nature 340:471-473.

Tomasiewicz H, Ono K, Yee D, Thompson C, Goridis C, Rutishauser U, Magnuson T (1993) Genetic deletion of a neural cell adhesion molecule variant (N-CAM 180) produces distinct defects in the central nervous system. Neuron 11:1163-1174.

Williams BP, Read J, Price J (1991) The generation of neurons and oligodendrocytes from a common precursor cell. Neuron 7:685-693.

Zamboni L, de Martino C (1967) Buffered acid formaldehyde: a new rapid fixative for electron microscopy. J Cell Biol 148A:35-41. 